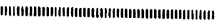

特別講演

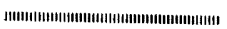

UDC $629.114 .6(047.3): 629.114 .6 .001 .8$

\title{
来た道行く道一自動車工業とともに一*
}

梅原 半 二**

\section{Past and Coming Years with Automotive Industry}

Hanji UMEHARA

\section{1.はじめに}

日本鉄鋼協会から武田東海支部長を通じ自動車工業の 過去・現在・未来について話をせよとのお話でした，不 幸にして私は自動車工業の経営の本流から啡れた中央研 究所という別会社におり,こういう問題は日夜その衝に 当たつており自らの体得がないと話に迫力が出ませんの で，私は適任でないと申し上げたところ，お前のいい題 で話をせよというわけで「来た道, 行く道」になつた次 第です. 今日の話は私がたどつた道であり，たどる道で あるということでご了承を得たいと存じます.しかも来 た道，行く道の中に現在が含まれていないということも 一つお含みいただきたい。

かえりみますと自動車工業というのは長い間輸出に弱 い産業でした．それにもかかわらずわが国の戦略産業と して早くから注目をうけ, 各方面から叱咜激励と政府, 鉄 鋼メーカーを始め材料関連産業, 部品工業などの絶大な 協力と国産品を使おうという顧客のいい知れぬ暖い気持 で育成され，現在ではトヨタだけでも GNP の $1 \cdot 3 \%$, 輸出 $2 \cdot 5 \%$ を分担する状況にまで伸長してまいりまし た. その報恩の気持からご期待に添い真価を発揮できそ うになつた現時点で，(1) 輸出の増大は悪であり，(2) GNP はくたばれ，(3) 交明よ退け，といつた方向一㑡 值観が流動してきています.しかも自動車には安全と公 害という問題がより切実で緊急問題となつています。こ れら公害安全の問題をテーマに自動車企業は膨大な研究 開発を進めており，公害と安全が技術問題のすべてだと いつても過言でない取り組み方をしています，それにも かかわらず，なお解明しないたくさんの重要問題をかか え，まさに自動車工業がかつて経験したこともない最大 のピンチに立つています. しかしこの道はいつか通らな ければならない道であり, 今論争の中心になつているの は時間の問題だけです. 長い地球の行く末を考光てみま すと,ここで 1 年や 2 年の差はそう大きな問題ではない のです. 場当たりでなく, 科学的地盤に立脚した策を実 行に移したいと思います。そしてその見通しがほぼでき
上りつつあることだけを申しあげておきます。

\section{2. 自動車生産の趨勢と自動車の本質}

図 1 は主要国の自動車生産台数の長期䟇勢1)ですが, アメリカは図のような伸び方をしており今も伸長が続い ています. 日本は戦後急激に伸びてきて, 1960 年頃から 世界の大生産国を一つ一つ抜いて現在ではアメリカの次 位になつています．この道は非常にきびしい坂道でし て，その間は実にいろいろな苦労の連続でした。

表lは 1971 年のデータで, 生産はアメリカが 1067 万台 ${ }^{2}$ ，日本は 581 万台というふうになつていますが， ここで星印のついていないものは過去最高の值です. 生 産では日本，西ドイッ，フランスが過去最高であり，自 国内の販売ではアメリカ, 西ドイッ, フランス，イギリ スイタリアが過去最高の新記録を出しています. 輸出 においてもイギリスを除いて過去最高の值を出してお り，しかも現在も伸長が続いており，たとえばアメリカ では 1972 年は1 400 万台くらい売れるだろうというよ うな非常に画期的な予測がなされています.

これらの数字は誠に不思議であります. 街に自動車が あふれ, 交通事故はふえ, 公害も鲧虑すべき状況に置か れているのは何も日本に限つたことではありません.だ が自動車はふえる. ライフ・サイクル論者に言わしめれ ば，もうとつくの昔にピークを描かなければならないは ずなのにこの図太さは一体何が原因なのであろうか.

自動車はいまやわれわれの生活と不可分の状況にあ り, そのかかわりの深さは全面的で, 人間がかつて造り 出した最大の生活ッールであります.

移動の喜び，ダイナミックでコンフォート（快適）な 機能が所有者の意志のままに奴隷的に奉仕する.しかも 車はプライバシーを尊重し, 外部との閉鎖指向性がある. 近代感覚を身につけた現代人には，自動車は最高の生活 道具で，それを使うことにより生活は魅力的ですばらし

* 昭和 47 年 10 月本会諈演大会にて発表 昭和 47 年 12 月 4 日受付

**（株）豊田中央研究所工博 
表 1 世界自動車統計 (1971 年)

\begin{tabular}{|c|c|c|c|c|c|c|c|c|}
\hline 項 & & $\begin{array}{ll} & \text { 国 } \\
\text { 単 㕸 } \\
\end{array}$ & アメリカ & 本 & 西ドイッ & フランス & イギリス & イタリフ \\
\hline 生 & 産 & 万 台 & $\begin{array}{c}1067 * \\
(95 \cdot 8)\end{array}$ & $\begin{array}{c}581 \\
(109 \cdot 8)\end{array}$ & $\begin{array}{c}398 \\
(103 \cdot 6)\end{array}$ & $\begin{array}{c}301 \\
(109 \cdot 5)\end{array}$ & $\begin{array}{c}220 * \\
(94 \cdot 0)\end{array}$ & $\begin{array}{c}182 * \\
(98 \cdot 2)\end{array}$ \\
\hline 登 & 録 & 万 $\%$ & $\begin{array}{c}1171 \\
(104 \cdot 7)\end{array}$ & $\begin{array}{r}403 * \\
(98 \cdot 0)\end{array}$ & $\begin{array}{c}231 \\
(101 \cdot 8)\end{array}$ & $\begin{array}{c}170 \\
(106 \cdot 7)\end{array}$ & $\begin{array}{c}157 \\
(107 \cdot 3)\end{array}$ & $\begin{array}{c}151 \\
(104 \cdot 5)\end{array}$ \\
\hline 輸 & 出 & ${ }_{\%}{ }^{\text {台 }}$ & $\begin{array}{c}60 \\
(107 \cdot 5)\end{array}$ & $\begin{array}{c}178 \\
(163 \cdot 7)\end{array}$ & $\begin{array}{c}229 \\
(108 \cdot 9)\end{array}$ & $\begin{array}{c}163 \\
(106 \cdot 9)\end{array}$ & $\begin{array}{r}92 * \\
(96 \cdot 1)\end{array}$ & $\begin{array}{c}68 \\
(101 \cdot 4)\end{array}$ \\
\hline
\end{tabular}

（）の数字は過去最高の值で除したものを\%で示す.*の付いていないものは過去最高の值である.

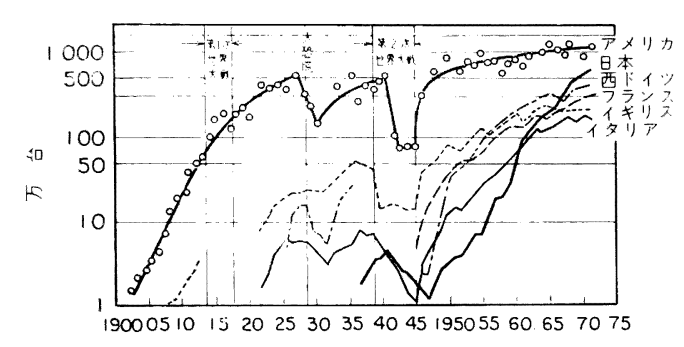

図 1 主要国の自動車生産台数の長期趨勢

いものとなる. そうでもない限り，この公害安全が庶民 のうちにわき上つているときに，庶民がこれほど自動車 を買うとは思われないのであります.

\section{3. 参議院での大論争 ${ }^{34)}$}

われわれもこの 20 年間に数百倍というように生産を 伸長してきました，過去をふり返つてみますと，どの場 面もいばらの道であり苦労の連続でしたが，妙に楽天的 でもありました.ここではその思い出のエピソードのう ち二，三をお話ししたいと存じます.

第一話として, 昭和 27 年 7 月 26 日参議院の運輸委 員会にメーカー，ユーザー，デーラーなどを交えた政府 代表, 運輸委員（議員）などによつて, 「乘用車の輸入 をどの程度にするか」これに関連して「国産乘用車を伸 ばすべきかどうか」の大論争が行なわれました.このと き自動車メーカ一代表としてトヨタの石田社長が出席 し, タクシー業者あるいは輸入菜者, その他から大変な 攻整を受けたのであります. その会議録が残つておりま す. 自動車工業発達の歴史をふり返るために非常に参考 になりますので,この会議録で話を進めたいと思います。

表 2 昭和 27 年 7 月 26 日参議院会議録拔粋(その1)

梁瀬長太郎氏 (OSA 委員)一一前略——軍が世話を して自動車製造事業法というものを作つて, 誰か 国産車を作らんか，私どもも再三惩涌されたけれ どもこれは算盤に合わない芸当ですからおやめに なるように，そうして外国と組むようにという案
を立ててあげたのですけれども，これが聞き入れ られなかつた、そこでトヨタさんが始めたけれど も一月に 200 や 300 作つて, 横から見ると情な いような始末であります.

\section{——後略—}

算盤に合わない以下のアンダーラインの部分は馬鹿で なければできないという意味です. 昭和 27 年当時, 卜 ヨタは 4 割の配当をしており，その時点でもこういう言 葉がきわめて自然に受け入れられており，てのときより 17 年も前に自動車を始めたのですから, みかけでは愚か な者でなければできない仕事であつたと思われます，愚 直でしかも先見性のある者でなければできない仕事であ つたと思います.この意味では創立者豊田喜一郎氏の偉 大さがしのばれます.

表 3 昭和 27 年 7 月 26 日参議院会議録抜粋(その 2 )

梁瀬氏：私の考えは，国産車は大体においてトラッ クとディーゼルのバスとに限定して乘用車はやめ なさい.フメリカのミシガン湖の北側から出るス チールでなければよくて値の安いスチールは得ら れない,というような細かいところまで私は知つ ている，乗用車には手をお染めにならんほうが経 済上却つてよくもあり，国家全体としてもまたお 徳用であります．これは乗用車製造者のために十 分にお考えになつたほうがお得であると, 差し出 がましいけれども私の 40 年の経験からそう言う のでございます.

当時の国産鉄板は本当に粗悪でした. しかも当時の価 格は鋼材がアメリカの 1.5 倍, 薄板が $2 \cdot 2$ 倍という状沉 でした.「ミシガン湖の北側で出る鉄鉱石でなければよ いスチールはできない」という通説が当時ありました. 今日世界一の安くてよい鉄鋼が日本でできるといううれ しい結果が出ましたので, 彼の「40 年の経験」も科学の 進歩には勝てませんでした。

表 4 昭和 27 年 7 月 26 日参議院会議録抜粋(その 3 )

梁瀬氏：何が国際貿易の上から日本で自動車をうま く作つてアメリカ品などに追いついていかれるか 
と調ベてみると，実に何にもありません．そこで こちらが研究をして五歩というときにはアメリカ は七，八歩進んでいる．この樊いをもつて行けば 算盤ずくでいつても 3 年, 5 年, 8 年, 10 年と進 むにしたがつてだんだん開いていく.いずれの日 かこれに追いつくことがありましょうか。

この言葉は今日でもしばしば耳にすることで一面の理 屈を持つています.これに対し石田社長は鋭意努力をす るからしばらく時を貸してほしいと強い決意をひれきし て, 政府関係の基本政策もあり, 乗用車工業を伸ばして ゆくことに决定したのです.この時の話を聞いて私ども は心ひそかに心配もし，一方では「燕雀いずくんぞ鴻站 の志を知らんや」とほくそえみ，自らを慰めて乗用車工 業確立のためにさらに一層の精励をし, いばらの道を登 つたのであります.

当時トヨタの主力はトラックであり, 乘用車は 150台 /月5)程度しか造つていませんし，相当に好況でしたの ので, 参議院のこともあつてその月に 11 万円を值下げ し, 以下表 5 ように矢継早に值下げを行ないました. 昭 和 30 年 1 月にはクラウンを発表した，これが私どもの エポックとなつたのです.

表 5 乗用車の值下げ経過（昭和27〜30年）

\begin{aligned} & \hline 昭和 27 年 6 月 $\begin{array}{c}\text { 生産台数 } 1368 \text { 台 } \\ \text { (うち釆用車 } 150 \text { 台) }\end{array} \\ &$ 昭和26年 121 万円 \\ & 27 年 7 月 110 万円 \\ & 9 月 102 万円 (新車) \\ & 29 年 4 月 100 万円 \\ & 7 月 91 万円 \\ & 30 年 1 月 クラウン 発売 月 400 台 \\ & \hline\end{aligned}

\section{4. 乗用車の 春 ${ }^{3)}$}

昭和 29 年 2 月, それまでの恒例の通産省委託で自動 車技術会第 3 回乗用車性能試験がありました. 参加車両 は国産乗用車のほかにヒルマン，ルノー，オースチンの 組立車も参加することになつており，国産車の見劣りを たいへん心配したのでした.しかし公式試験では国産車 の性能は相当のものであることが実証されました.

数多くの試験はいずれも数字で出てくるようになつて いました・たとえば車室密閉度試験では沼津の千本松原 といつた当時未舗装でほこりの立ちのぼる所を何時間も

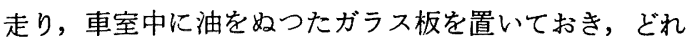
だけほこりがたまつたかを重量をはかるといつた方法に より順位を決めたのでした.

これらの試験が終了し, 試験委員や各参加メ一カーの 関係者たちが一堂に集合した 2 月末のある日，試験委員 長の山本峰雄教授は私に, 「国産車を代表して感想を述 ベよ.」と惩汿されたので, 私は心の中に浮び上つてきた 次のような言葉を贈つて挨拶に 代えたのである.「今回

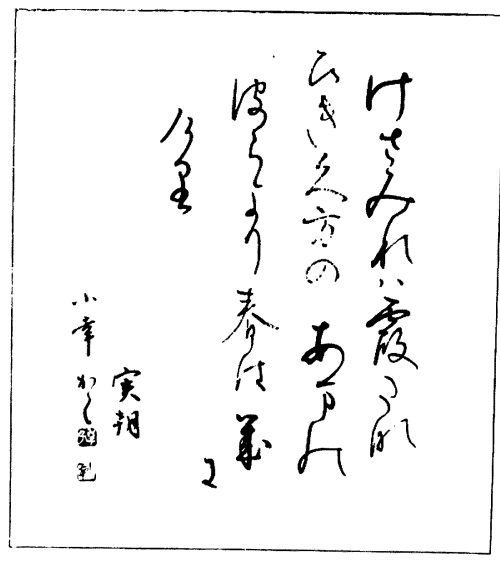

図 2 実朝 $の$ 歌

の性能試験で, 国産車が案外好成績を収めえたことは, まことに感慨無量であります。私どもは今，“今朝みれ ば霞たなびき久方の 天の原より春は来にけり (実朝)” （図2）といつた気持であります.いつまでも寒いなあ, どうしてこんなに寒いのだろうか，外には雪がまだそこ にもここにも残つている……思いながらふと空を開け てみると，空の彼方にはもう霞がたなびいているではな いか, ああ，こんなに寒くともやはりもう春は来ている んだな……といううな気持を歌つたものであります.

私どもの生産している自動車が, いつまでも寒い自動車 だとばかり思つていたのに，今日の試験によつて，国産 車の上にも春がやつてくるのは間近いのではないかとい うことを痛切に感じた次第であります.」

さてこのような情勢を背景として国産車の完成期も間 近いことは明確になつていたと確信を高めたのでした. しかしこのことも少々思いすぎでした. 当時は名だたる 悪路であり, 乗用車の走る道ではなかつたのです. そう いう道に適した車を作つていたのですから悪路で成績の よいのは当然であるということをもつと反省すべきであ ったと思います.

\section{5. フォードとの関係}

つぎにフォードとの関係を括しします.私どもは自 分の力を知つているので，どこかとなんらかの形で提携 するといいと思つていました. 昭和 13 年頃からたびた び提携の話がありまして，その経過を示したのが表 65) です.

このうち昭和 35 年 6 月の最後の交涉経過を申しあげ ます.フォードとトョタで合併会社を作つてパブリカを 製造販売することで話が進みました. 当時試作完成した パブリカについてのテストをして，先方は OK をしま した. そのとき, 設計は何人でやつているかと聞かれた ので, 基本車種 10 くらいを 150 人くらいでやつている 
表 6 フォードとの関係

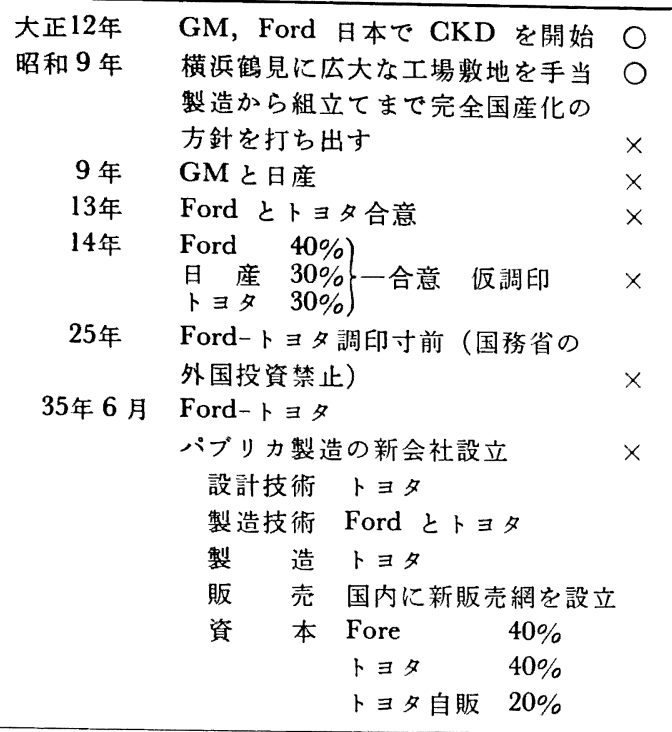

$\bigcirc$ : 実現, $\times$ : 不実現

と答えると wonderful と言いました，総体に車の性能と か設計には重点がなかつたように思いました。

私どもは極秘の手の内を全部さらけ出してしまつたの ですが，指導権をどちらがとるかということで意見が合 わすここの話は立ち消えとなりました，その結果トヨ夕は たいへえ損をしたように感じましたが，ただその時つォ 一ドの技術者の一人がこういうことを言いました。

（1）フォードと組をとボデーはたいへん安くなりま す.とりわけドアーラインの能率があがりますよ.

（2）フォードは日本へは日本の道路がもつと乘用車 が走るにふさわしい状態になつてからでないと本格的に 進出をしない。

という二つのヒントを与えてくれました．もともとボ デーとりわけドアーの製造方法の弱点は私どものその道 の専門家ではよくわかつていたのですが，専門でない私 には強い印象的な言葉として後々まで銘記されていたの です.

また道路の話はその年, 昭和 35 年にアメリカへ乗用 車を輸出しましたが，フォードが日本へ進出するのを踫 躇しているのと同じょうに, アメリカと日本では道路が 全然ちがうんだ，そういう違う環境でテストをして車を 輸出したつて売れるはずがない，ということに大きな関 心を持たなかつたことが当時のアメリカ輸出が失敗した もとで, 名神高速道路ができた昭和 38 年以降をで自重 せざるを得なかつたのでした．

いろいろと含みの多い忠告を受けたという点で, つょ ードとの話は私の方にもプラスがあつたと思います。

\section{6. 自動車に占める鉄鋼と鋼板のプレス成形}

自動車がどのくらい鉄鋼を使つているか，1 例を表 7 に示します. この表では $46.9 \%$ が鉄板， $14.5 \%$ が棒鋼 鋼管， $13 \cdot 8 \%$ が鉡鉄，その他非鉄金属が $5.8 \%$ ，ほかに ゴムとか樹脂とかガラスとかそのほかありますが $19 \%$ にすぎません. $81 \%$ が金属で, 自動車は金属の塊りで あり，しかもその $50 \%$ は鋼板であるということであれ ば鋼板の話に移つていかなければならないわけでありま す.

図 37) はトヨタのプレス加工自動化の変遷ですが，フ ォードとの話のあつたのは図の AA の時点です.そして 次のプレスラインを作ろうとしていたわけでした．そこ でDanly 会社のプレスを買入れてドア,プレスラインを 作ることになつたのです.このとき副社長の Don DANLY 氏が来ており売買の交涉がすすみ，最後の調印をすると いうときに，D. DANLY 氏が急にアメリカに帰らなくて はいけない事情が拈き，予定の日より早くサインをする 必要がおこりました．今すぐサインをしたい，不幸にし てその日トヨタの代表取締役は私一人しか在社していま せんでした．私はかねがね，フォードの技術者から聞い たことで，大変関心を持ち，私の頭にこびりついており ました. door line は大切だ, 早くしたい, という希望 があつたわけですから，よからうとサインをする決意を しました．ふと值段を見るとそれが７億円以上です．私

表 7 中型乘用車の材料別重量棈成比率

\begin{tabular}{|c|c|}
\hline 材 & \% (重量) \\
\hline 鋼 板 & $46 \cdot 9$ \\
\hline 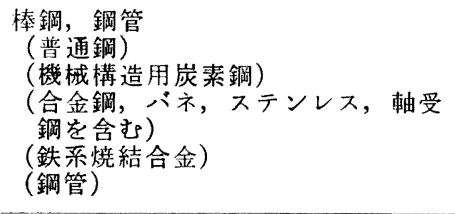 & $\begin{aligned} 14 \cdot 5 & \\
& (1 \cdot 4) \\
& (5 \cdot 4) \\
& (5 \cdot 9) \\
& (0 \cdot 2) \\
& (1 \cdot 6)\end{aligned}$ \\
\hline 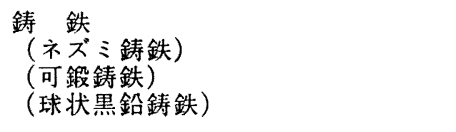 & $\begin{array}{r}13 \cdot 8 \\
(11 \cdot 8) \\
(1 \cdot 0) \\
(1 \cdot 0)\end{array}$ \\
\hline $\begin{array}{l}\text { 非鉄，その他 } \\
\text { (アルミニウム合金) } \\
\text { (銅, 亜鉛合金その他) }\end{array}$ & 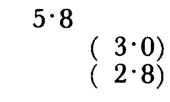 \\
\hline 金属材料 計 & 81 \\
\hline 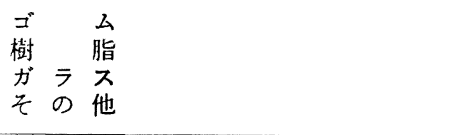 & $\begin{array}{l}6 \cdot 8 \\
2 \cdot 1 \\
5 \cdot 6 \\
4 \cdot 5\end{array}$ \\
\hline 非金属材料 計 & 19 \\
\hline & (累計 100) \\
\hline
\end{tabular}




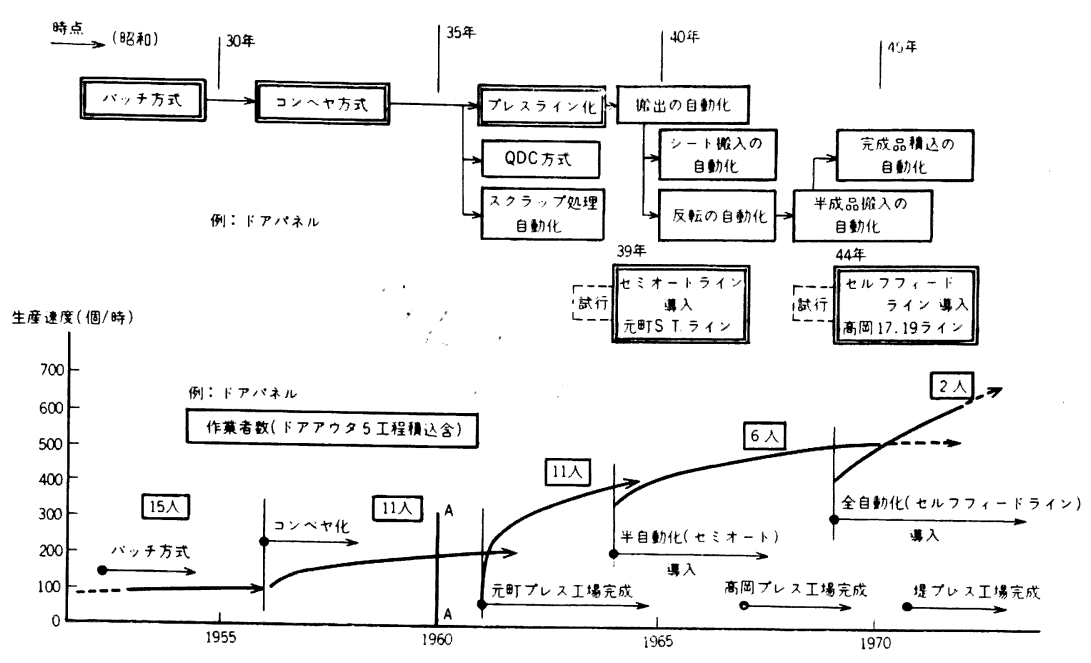

困 3 トヨタのプレス加工自動化の変遷と生産速度の向上曲線

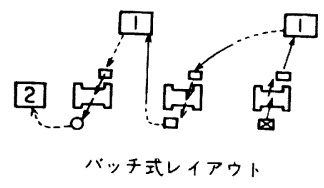

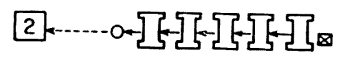
连珫レイアゥト

図 4 プレスのレイフウト方式

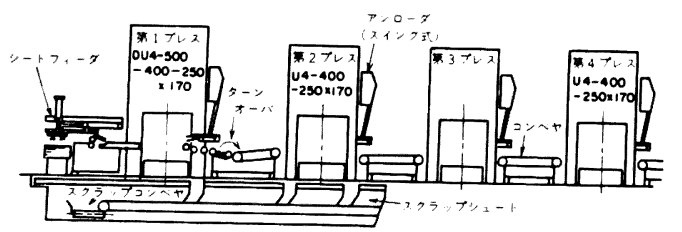

図 5 元町 $\mathrm{S}$ or $\mathrm{T}$ 半自動ライン構成困概要

表 8 Danly door press line

$\begin{array}{ll}\text { (1) 入荷の時期 } & \text { 昭和 } 35 \text { 年末 } \\ \text { (2) メーカー } & \text { 米国シカゴ市 Danly 社 } \\ \text { (3) 特 長 } & \end{array}$

(a) 生産能力

導入当初 毎時生産速度 350 個（6 名）

現在" 500 個 (6 名)

（b）中間工程におけるプレスへの物の送り込み 以外はすべて自動的である.

（c）型の交換が迅速にできる.

(d) アンダドライププレスであり歌動部分は床 下に収納.
は技術関係ですから物を買つたことがない，一番初めに 買うのが 7 億円では少しためらいを感じました. 私はア メリカ人気質といいますか，アメリカ式に交涉をしたい と思い，私の業務には睡買関係はない，それがあえてサ インをするので後で余分なことをしたと言われるかもし れない，ギブアンドティクの世の中だから何か方策はな いか，というように相談をもちかけました。 では1万ド ル引くからサインをしてくれ, と先方から話が出ました. よろしい，サインをしましよう，という次第でこの商談 は決着がついたのでした・（表 8)

図 3 にプレスラインの変遷が示してありますが, 初め の頃のバッチシステムというのは, 一遍プレスをしてた めておき，またプレスをするというレイアウトです．次 に図 4 に示すように連続的にプレスするように変わりま した. 図 5 は半自動ラインの構成概要です. 半自動では ローディングだけは手でやつていたのですが，それも自 動化されたのです. いまこの全自動化ラインが元町, 高
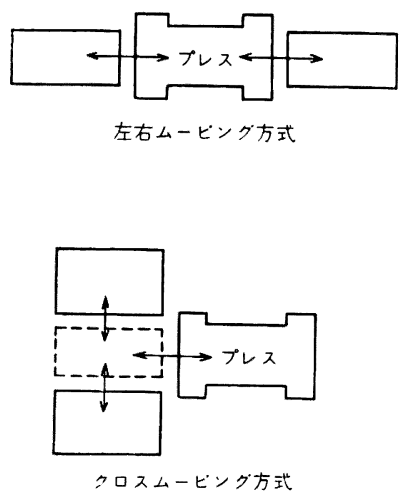

四 6 QDC の各方式 
表 9 型交換時間の向上

\begin{tabular}{|c|c|c|c|}
\hline & 普通プレス & $\begin{array}{l}\text { QDG } \\
\text { プレス }\end{array}$ & $\begin{array}{l}\text { 最近の } \\
\mathrm{QDC}\end{array}$ \\
\hline 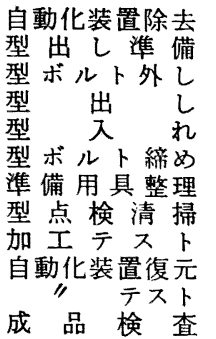 & $\begin{array}{l}7 \cdot 5 \text { 分 } \\
3 \cdot 5 \\
5 \cdot 5 \\
8 \\
10 \\
7 \\
2 \cdot 5 \\
3 \\
5 \cdot 5 \\
9 \\
12 \\
10\end{array}$ & $\begin{array}{l}3 \text { 分 } \\
0 \cdot 5 \\
1 \cdot 5 \\
1 \cdot 5 \\
1 \cdot 5 \\
2 \\
3 \\
5 \cdot 5 \\
5 \\
6 \\
10\end{array}$ & $\begin{array}{l}0 \cdot 5^{\text {分 }} \\
0 \cdot 5 \\
1 \cdot 5 \\
1 \cdot 5 \\
1 \\
3 \\
5 \cdot 5 \\
6 \\
10\end{array}$ \\
\hline $\begin{array}{l}\text { 合 計 (分) } \\
\text { 作業人員 (人) } \\
\text { 工 数 (人・分) }\end{array}$ & $\begin{array}{c}83 \cdot 5 \\
2 \\
167\end{array}$ & $\begin{array}{c}39 \cdot 5 \\
1 \\
39 \cdot 5\end{array}$ & $\begin{array}{c}29 \cdot 5 \\
1 \\
29 \cdot 5\end{array}$ \\
\hline
\end{tabular}

表 10 Door 用 Delta welder line

$\begin{array}{ll}\text { (1) 又荷の時期 } & \text { 昭和 } 38 \text { 年 } \\ \text { (2) メ - }- & \text { 米国デトロイト市 } \\ & \text { Delta Welder Co. }\end{array}$

(3) 特 長

(a) 生産能力

導入当初 毎時生産速度 150 個

現在" 360 個

（b）各種類のドアが溶接組立できるようにプレ

ス型に相当する治具（フィクスチュフと称 する）が交換できる.

（c）パーツのラインへの送り込み以外はすべて 自動的である.

（d）従来の手作業による溶接に比して強度，寸 法精度のバラッキが少ない。

（4）その他

この種の設備はその後改良され，国産化され て現在トヨタ自工のみでも 10 ライン以上が 使用されている.

岡そして堤の各工場に数十ラインあります.

それから型を取りかえるのに QDC(Quick Die Change), 早く型をはずす方式を図 6 に示しました. 左右ム ービングシステムとクロスムービングシステムのニつの システムがありますが，そのQDCの方式を採用して， 型交換に要する人員を比較したのが表 9 です.

表 10 はドアーを作りますのに外はんとか内はんとか を溶接していくんですが，それを自動化する，しかも何 種類もの weld ができる, プレス部品をただ送りこめば 後は自動的にできるというのを Delta Welder Company から買いました.この設備はその後改良され，国産化さ れて, 現在トヨタ自エだけでも10 ライン以上が使われ ています.

終戦後の乗用車ボデー生産の歴史をふりかえつてみま すと, 昭和 24 年にそれまで禁止されていた乗用車の生
産許可が GHQ から出まして，昭和 26 年頃から生産を 開始しましたがボデーは外注でした。初期の頃はボデー を作るのに 800 時間もかかり，1時間 1000 円とします と 80 万円もかかつたのでした。 それが昭和 29 年頃や つと 400 時間となり, 昭和 30 年になつて初めて自社内 での製作を開始しました，それでも 80 時間くらいかか つたのですが，現在では前記の努力の結果，車種によつ て変わりますが 5 時間内外でできるようになりました。

\section{7. 鋼板使用の合理化}

昭和 35 年頃から鉄板の合理化を強くおし進めました。 以下の話はこれに尃念しました藤本 俊君（トヨタ自工 取締役）らがやつた概要です.

(1) 歩留まりの向上

板取りの合理化が第一に考えられます．無論このこと は当初から誰でもねらら問題ですが，材料が著しく向上 し，かつ鉄板の製作方法が進歩した段階で基本的に検討 を初めたわけです. 歩留まりの向上にはコイル化が第一 である.コイルなれば勝手な寸法をとることができる. ところがコイル材は外観不良がどうしても出る. 初期の 頃は $20 \%$ も不良になつたのですが，最近は非常に向上 してきました：このことは主として鋼板メ一カーの努力 によります.

つぎにビードの形状，シワ押えの形状などの合理化の ため張り出し成形法などを検討していきました．またス クラップの再利用なども考えをした：これらの努力は図 7 のような歩留まり向上となつて結実しました. しかし コイルの表面キズについてはメーカーも検査の自動化な ど大きな配虑がなされていますが，まだ若千の問題を残 しています.

(2) グレード・ダウン

キルド鋼板でも往々にして時効効果が出るものもあり ますが，リムド鋼板では時間がたつとストレッチャース トレンが出ます．それで普通鋼をメーカーでスキンパス を通したものを時を移さず工場に持ち込み，また時を移 さずプレスするというのが大きな䦗題として取り上げら れ，このリードタイムを短くし， just in timeを心掛け

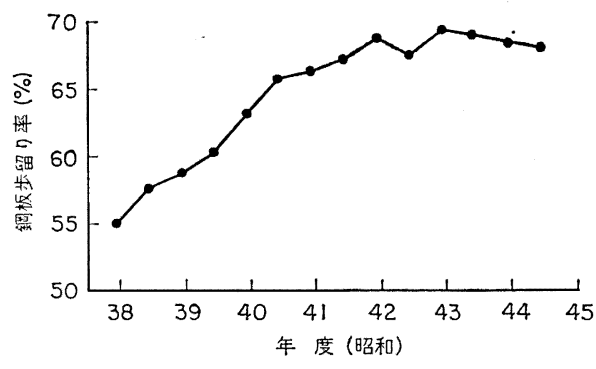

困 7 乘用車メーンボデーの材料歩留まり率の 推移（ある車種の例） 


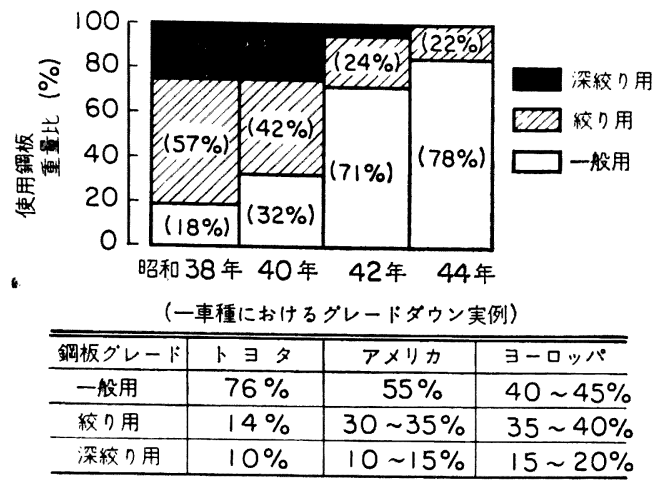

図 8 乗用車ボデー外板部品の使用鋼板構成

表 11 材料 の 合 理 化

1. 歩留り向上

（イ）コイル化，スケッチサイズ化

（ロ）成形方法の検討

張出し成形（ビードの形状，シワ押え形状）

(八) スクラップの活用

2. グレードダウン

(イ) Just in time

（口）材料特性と加工結果

（八）成形方法の検討

成形限界の把握

たのであります．また延びとか，エリクセン值とか，コ ニカルカップテスト值といつた材料特性と加工結果の相 関を詳細に実験でたしかめました. 成形方法の検討を行 ない，成形限界の把握につとめました．プレスする部品 の絞り程度を数值化しまして，この数值のものであれば この程度の鋼板でよろしい, といつた判断がつくように なり，鋼板のグレードを逐次下げることに成功しました． その結果が図 8 のように欧米のどこより一般用鋼板の使 用割合が多くなつたのです.これができたのもわが国の 鋼板の優秀なことともつながつているのであります. し かし板厚を合理化していくと張り剛性が問題になつてく るようになり, 設計上の考虑も急伸展しました. この章 をまとめたものを表 11 に示しました。

\section{8. 自動車鋼板の開発 ${ }^{8)}$}

自動車用鋼板は自動車と材料メ一カーとが共同で次の ような開発が行なわれました。 まず材質上の開発を申し あげます.

(1) 低降伏点鋼板

これは鋼中の $\mathrm{C} ， \mathrm{~N}$ などの不純物を少なくし，さら に結晶粒を大きくすることにより鋼板の降伏点を低く し，スプリングバックなどの加工後の形状性の問題に対 処してきました.
（2） 遅時効性鋼板

これは自動車メーカーにおける材料管理などの点より 一時大きな問題であったが, 低咥素吹鍊, アルミ脱酸など を中心に主として低窒素鋼によりかなり解決しました.

（3）超深しほり用鋼板

一時 $\mathrm{Ti}$ 添加鋼板が使用され好結果であったが，コス トの点から現在で淰 $\mathrm{Al}$ キルド鋼, 脱炭脱空焼鈍材など が使用されています.

(4) Just in time 材 (前出)

また外観上より

(5) デフォレンシャルダル材

鋼板の片面の粗度のみ極端にあらくすることにより， プレス時に飛びこむゴミによるくぼみを目立たなくさせ ることを狙いとしている．この材料はまだ一般的ではあ りませえ.

さらに最近の安全対策関係にからんで次のような動き があります.

(6) AA 鋼 (Accelerated Aged Steel)

プレス時には軟かくて加工性があるが，後の自動車の 塗装焼付工程で $160^{\circ} \mathrm{C}$ 程度に加熱されることにより鋼 中の $\mathrm{N}$ などが析出して鋼を強化することを目的として います.

(7) 高張力鋼板

安全車としてのバンパー用鋼板など “高張力の 新材 料”が要望されます.これには種々のものが鋭意研究さ れていますが，まだ開発途上の段階であります.

\section{9. 鋼板圧延用タンデムミルの電算機制御 ${ }^{9101}$}

以上述べてきましたようにわが国の鉄板がメーカーの ご努力でよくなつたのでして，次に鋼板圧延用タンデム ミルの電算機制御について申しあげたいと思います. 図 9 にタンデムミルの1 例を示しましたが，これの運転を 計算機で自動制御する. 厚みを自動的にはかつてそれを 困のようにフィードバックしてロールの間隙を調節し,

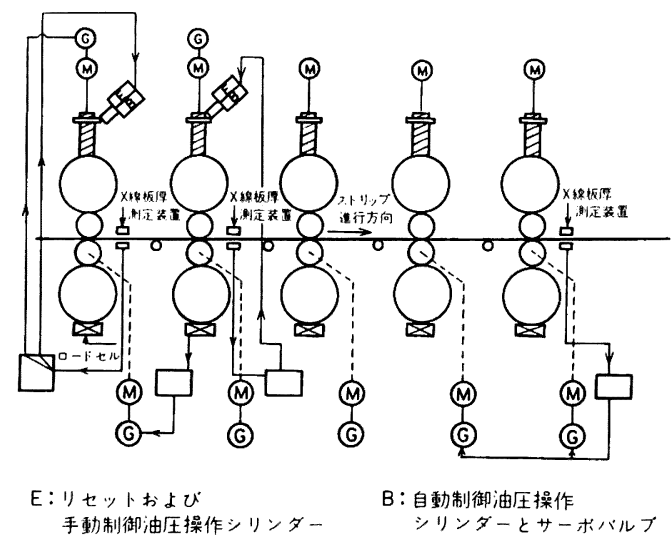

図 9 タンデムコールドミルの自動板厚制御機構 


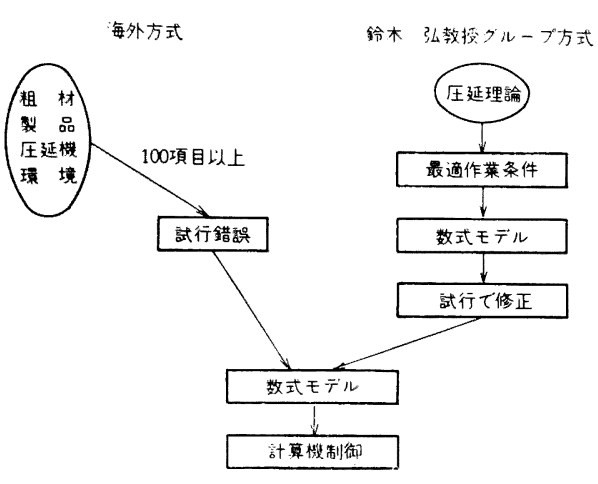

図 10 タンデムミルの計算機制御方式

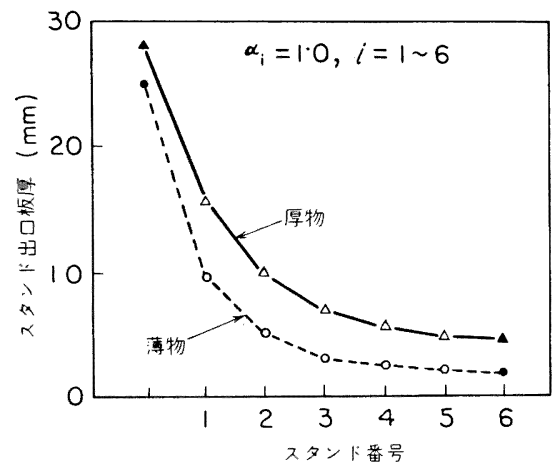

図 11 製品形状の最適パススケジュール

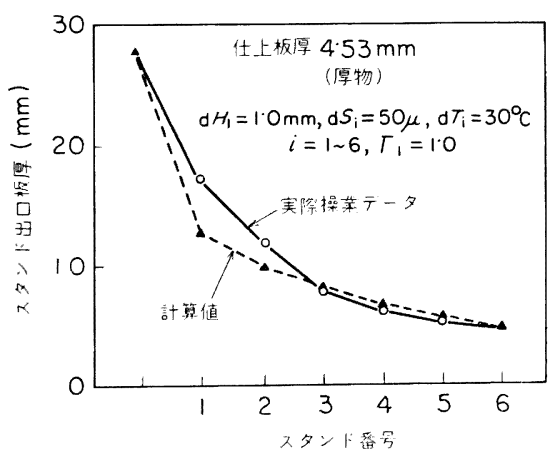

図 12 製品板厚および製品形状の長手方向変動の パススケジュールと実際操業データとの比 較（厚物サイズ）

板の厚みを調節して均一な板厚の製品を連続的に作る. この方法は海外から導入されたのですが，別に東大の鈴 木弘先生グループが理論的解析を基盤として全く独自の 数学モデルを作りました. その比較を図 10 に示しまし た.まず理論から最適パススケジュールを計算し, 図 11 に例示するように厚物ではこのように压延するのがよ い，薄物ではこのように圧延するのがよいという結果が

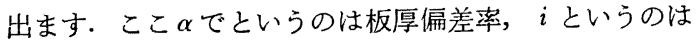

スタンドの番号でここでは六つのスタンドの場合につい て計算してあります. 最適パススケジュールにそつた数 式モデルを電算機に与えて実際に操業しますと図 12 の ようになり，この結果で数式モデルを修正する.

繰り返しますと従来の方式ですと粗材とか, 製品とか, 圧延機とか，環境これは温度が主力なんですが，そうい う要素がいろいろ組み合わさつた形のままで試行鍇誤を して数式モデルを作り計算機制御をするという方式を採 用していましたが，鈴木先生は一番初めに圧延理諭から 最適作業条件を求めて数学モデルを作り, 試行でこれを 修正しそして数式モデルを完成したわけでありまして， こういう計算機制御ができるようになり，且，すなわち 板の末端を稼動しながら溶接することができる技術が完 成して，四六時中運転することが可能になりました．そ れからもら一つ，ロールを稼動している状態で厚みを变 えることができるというようなことがこの方式では可能 になつたのでありまして, 鈴木先生のお話を伺いますと， 今後 3 年くらいは外国の追従を許さないであろうという ことです.それを一番初めにやられたのが日本鋼管の福 山工場でございます.

\section{0． 産産協同と産学協同}

鋼板のほとえどすべてが複雑な条件のもとで，プレス 成形されますので，鋼板の品質とくにプレス成形性が問 題になります.

図1311) はエリクセン值を尺度として, 戦後の薄鋼板 品質の推移を表わしたものです，乘用車生産が始まつた 頃の国産冷延板の品質はきわめて悪く, 成形歩留まり不 良，引張りひずみ発生等が続いた。 そこで昭和 27 28 年頃から，自動車工業会では鉄鋼メ一カーに対し自動車 生産に適した鋼板の供給を強く要求しました．また自工 会を通してアメリカの鋼板を輸入し，その品質を協同で 調査したこともあります。図には当時鉄鋼メ一カーで自 動車用に試作した鋼板や，輸入鋼板の試駼結果も記入し てあります。

このこととは別に, トョタでは八幡,富士と別々に鋼板 連絡会というのを作り，年に数回会議を開き，それが今 日まで連綿と続いており大変効果をあげました．現在の 国産鋼板の品質は世界一流のレベルに達しています。× 一カーとユーザーとの関係がよかつた例としてお話しし ましたが，アメリカなどの場合から考えてさらに一層の 産産協同が必要と思います。

一方これらの動きと平行して, 薄鋼板のプレス成形性, 成形技術に関する研究会が 自動車メ一カー，鉄鋼メ一 カーと福井伸二博士, 吉田清太博士などを中心とする学 者グループによつて結成され, 情報交換, 協同研究の場 となりました．成形性の尺度としてのコニカルカップ試 験，成形技術の基礎としてのスクライブドサークル試験 などはこれらの研究会活動によつて普及し，薄鋼板のプ 

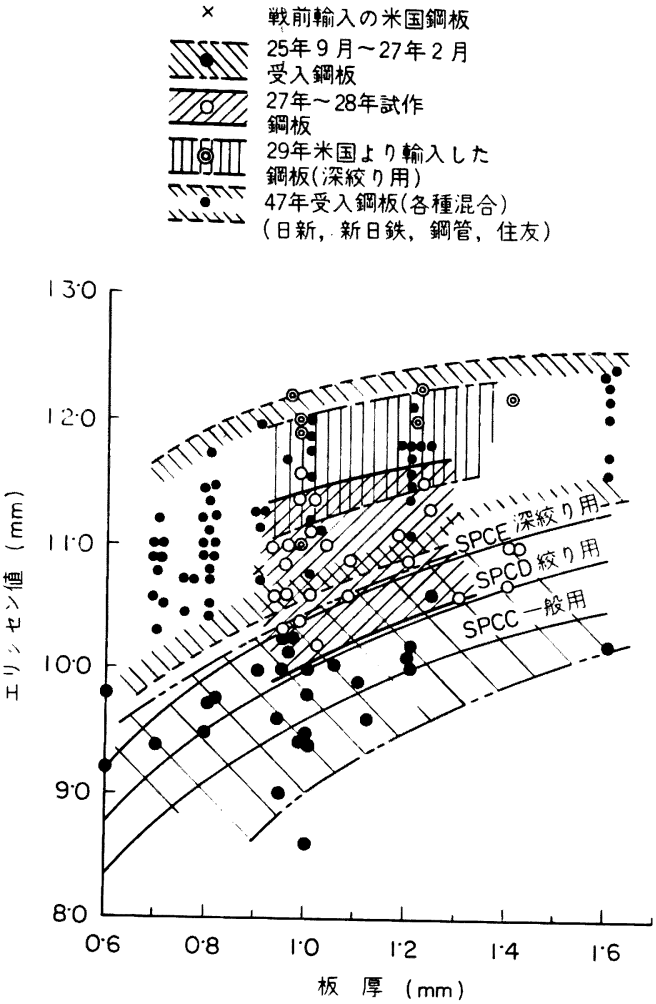

因 13 鋼板材質の向上

レス成形技術の発達に大きな役割を果たしました。

図 14 は種々の等級の鋼板につき,引張り試験における 伸び值，エリクセン值およびコニカルカップ值の分布を 比較したものです.鋼板等級の区別は, 伸び值よりエリク セン值，エリクセン值よりコニカルカップ值によく現わ れています. また各プレス部品の成形時の塑性変形状態 はスクライブドサークル試験によつて把握され，この結 果は使用すべき鋼板の等級决定にも有効に役立つていま す. 産学協同の1例としてお話ししました.

\section{1. 薄板価格と自動車価格の変遷}

われわれが自動車生産に踏み切るときにはさまざまな 危惧がありました. 自動車は板厚 $1 \mathrm{~mm}$ 中心の薄鋼板を 主に使用していますが，その頃はこれより薄いトタン用 の需要が多く $1 \mathrm{~mm}$ 厚みのものは法外に高かつたのでし た. それが鉄鋼メーカーのおかげで逐次改善されアメリ カ並になり，さらにはアメリカを淩駕するという状況に までなりました.図 1512)，16，17 に向上の推移を示し ました.それと同時に自動車の価格も図 18 に示すよう に急激に下降しました。

参考までに図 19 にトヨタ自工における決算期ごとの 販売台数当たり売上金額を示しました. この中には物品
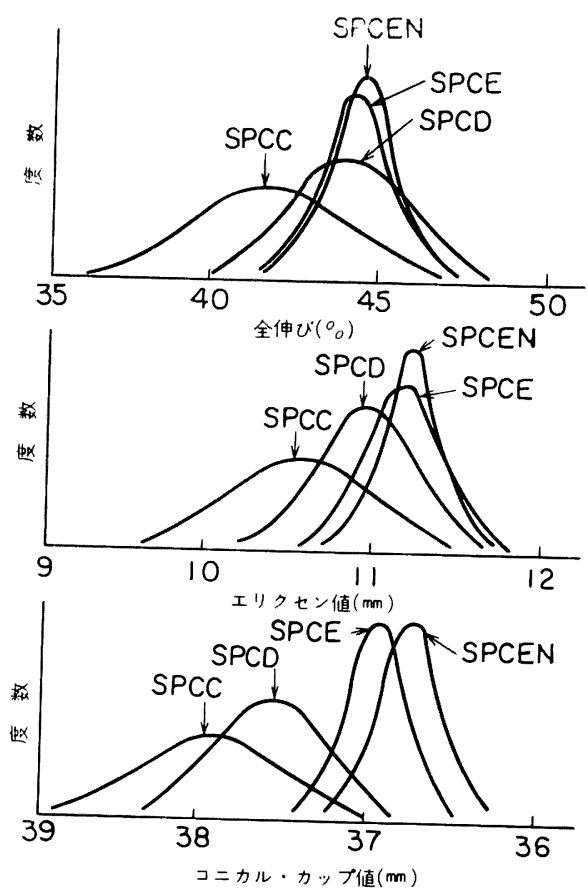

図 14 鋼板等級別プレス評価值の分布

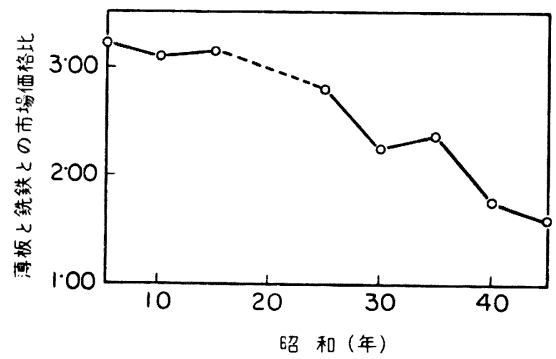

図 15 薄板と鉄鉄との価格比の推移

税, 部品代を含んでおり，時代とともに大衆車が多くな りましたし，一方ではデラックス化もありますので必ず

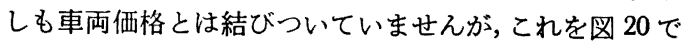
アメリカにおける乗用車の平均卸売価格と対比していた だきたいと思います. 図 21 はトョタ自工における 1 人 当たり年間生産台数が生産の増加とともに向上している 状況を示しました. 横軸に生産台数をとりましたが，こ れは時間を横軸にとつてもほぼ同じような向上曲線にな ります.このように生産能率の向上は, 生産増加と別に 時をかけて合理化がすすむこととの相乗結果と思われま す. 生産增加は今後, 今までのように急増するとは思わ れませんので, 時をかけて合理化を進める，言いかえま すと時間効果をねらうべきであり，これには各方面の科 学的解析が必要と思います. 


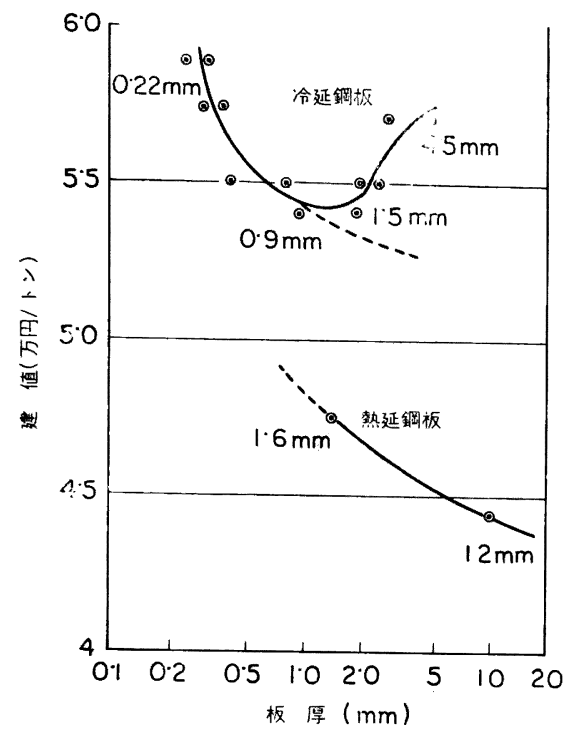

困 16 板厚と価格の関係（昭和 44 年）

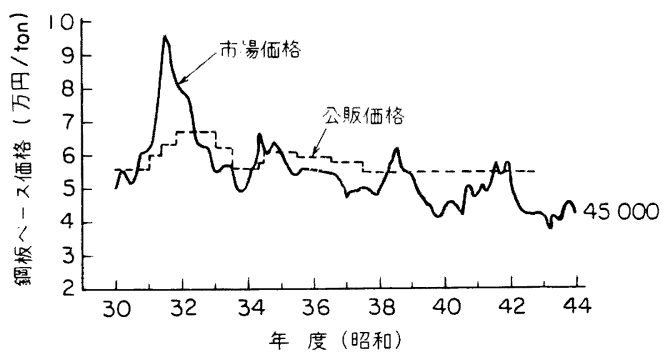

図 17 鋼板のベース価格の変動 $(0.8 \mathrm{~mm}$ 冷延板 $)$

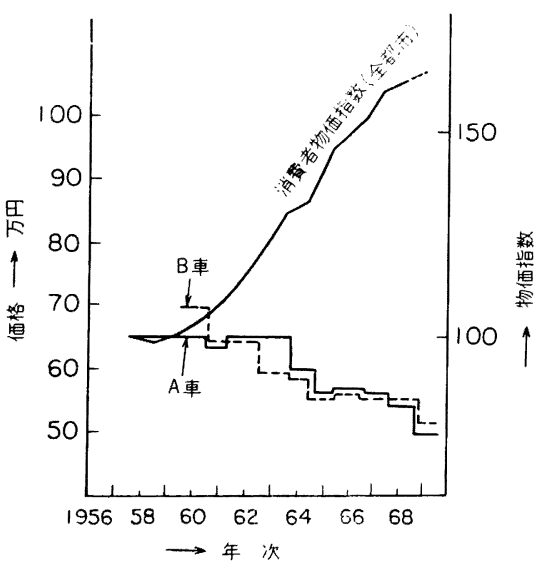

図18 わが国の $1500 \mathrm{cc}$ 級乗用車の価格推移と 物価指数

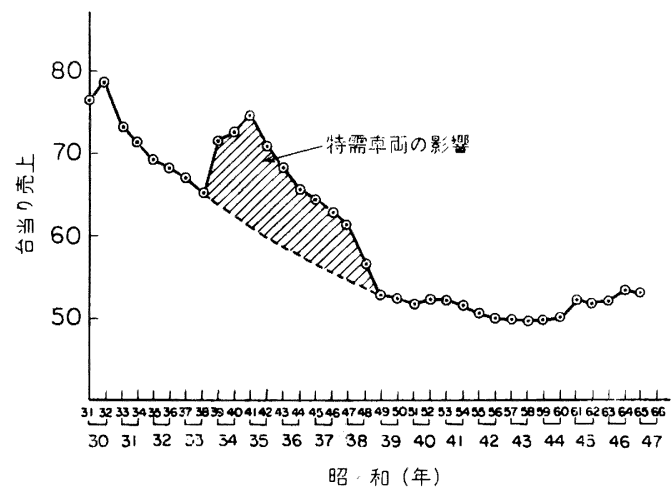

図 19 台当たり売上金額 (トヨタ自工)

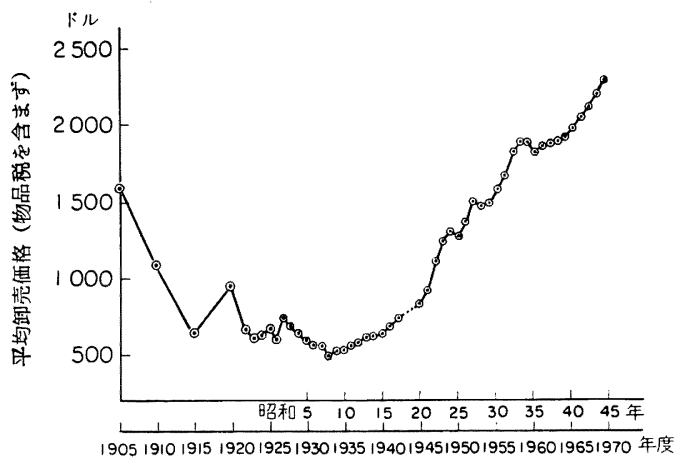

図 20 アメリカにおける乗用車の平均価格

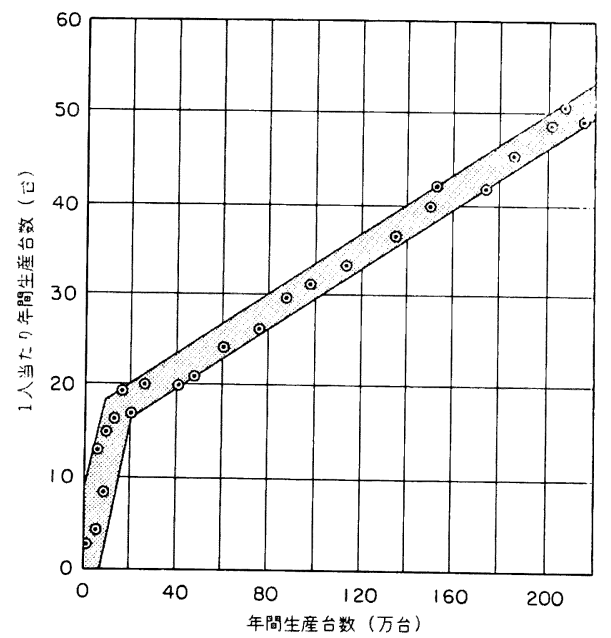

因 21 量産による生産性の向上（トヨタ自動車工業） 


\section{2. 行 < 道}

自動車生産は従来よりゆるやかな伸長となると思われ ますが，ごく近い将来の予測を図 22 に示しました。さ らに遠大な将来について「行く道」を申しあげます.

過去をふり返つてみをすと自動車工業の大課題として 戦争という大きな課題があつたし, 自由化とか資本の自 由化という大きな課題がありました. 今は環境問題とい うのが最大の課題であり，この環境問題も1980 年頃に は第一段階の解決はつくであろうと思つています. 私ど もはポストマスキーといつていますが，この問題が解决 しますとまた自動車のリバイバルがあると信じていま す.このリバイバルは 1980 年頃からはじまるでしよう . 今の横ばいになつているのがやや伸びるであろうと思い ますが, 基本的には量より質への転換の時代に移ります.

さらに次の大きな段階はエネルギー問題であります. エネルギーは無限にあると思うと大変な間違いで, 現状 では太陽光線のエネルギーに比べわれわれの作り出すエ ネルギーは 1 万 5000 分の 1 にもなつていますが，かり に現在までと同じようにエネルギー使用が年々 $5 \cdot 5 \%$ ふ えていつたら，2100 年の少し前には地球の温度は 12 ${ }^{\circ} \mathrm{C}$ むあがると計算した学者があります. そうなると大 変なことになります．海面の水位は $50 \mathrm{~m}$ もあがり，乙 かも緯度 50 度以上でないと暑くて誰も住めないという ような時代が来るのです.エネルギーは核エネルギーの みに頼るということでなしに，根本的には太陽エネルギ 一の活用が必要となります.太陽エネルギーであれば地

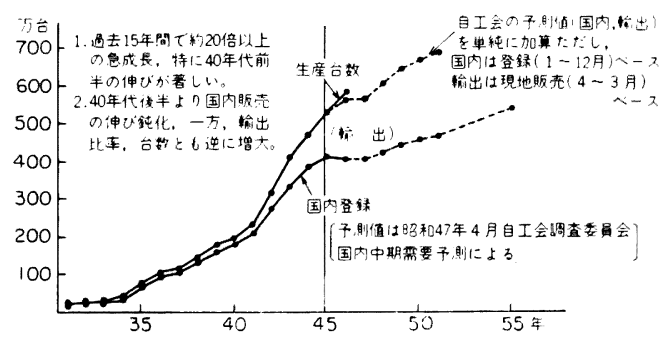

図 22 生産, 販壳台数の推移 (対象台数は軽, 三輪を含宫)
球の熱収支はコンスタントになります．このエネルギー 問題は 2000 年頃を目標に解決の系口を見い出さなけれ ばなりません. その後で 2nd Automobile Revival とい うものが始まるでしよう．そのブループリントは少なく とも 2000 年には作りあげねばならないというのが私の 考えであります.

\section{3.おわりに}

この話の哲理をまとめます. カントは「直観なき概念 は空虚であり，概念なき直観は盲目である」と言いまし たけれども，私は（1）「技術なき科学は空虚であり，科 学なき技術は盲目である」と申しあげたい.そして (2) 「工学は常に経済と結びついている」，(3)「量産効果時 代から時間効果の時代に遷移しつつあるが，技術戦争は 悠久に続く」とこの三つの哲理を今日はお話ししたので ございます．最後にこの講演の資料を集めるに当たりま して, 武田喜三支部長はじめ新日本製鉄の若松善英君ら に大変ごやつかいになりました. また鈴木 弘教授ほか 本文または脚注記載の方々と，全体の構成に協力を得た 新見 格君らにお礼を申しあげて私の話を終わりたいと 思います.どうもありがとうございました。

\section{文献}

1) モーターフォン揭載の日本産業材料研究所作成の ものに書き加えた。

2 ) 梅原: 自動車とその世界， 6 月号 (1972), p. 2

3 ) 梅原: 日本の自動車技術 20 年史 (1969), p. 64 （自動車技術会発行）

4 ) 第 13 回国会参議院運輸委員会会議録 36 号

5) 卜ヨ夕自動車 30 年史 (1969)

6 ）書家 栗原小幸作

7 ）小林德夫：プレス技術，9 (1971) 11，p. 80 図 3〜6, 表 8〜10 は小林德夫君作成

8 ）この章は今林格君（新日鉄）の協力を得た

9 )この章は鈴木 弘教授から沢山の資料をいただい た。

10）鈴木 弘，岡戸 克：塑性と加工, 10 (1969) 106

11) 青山成恒君（豊田中研）ら作成

12）小島慶三，中島淳夫：鉄，（1957），（鉄鋼と金属 社）の数值を一部採用 